\title{
SOCIAL ENTRAPMENT EVIDENCE: UNDERSTANDING ITS ROLE IN SELF-DEFENCE CASES INVOLVING INTIMATE PARTNER VIOLENCE
}

\author{
HEATHER DOUGLAS, ${ }^{*}$ STELLA TARRANT ${ }^{* *}$ AND JULIA TOLMIE ${ }^{* * *}$
}

This article considers what evidence juries need to help them apply the defence of self-defence where a woman claims she has killed an abusive partner to save her own life. Drawing on recent research and cases we argue that expert evidence admitted in these types of cases generally fails to provide evidence about the nature of abuse, the limitations in the systemic safety responses and the structural inequality that abused women routinely face. Evidence of the reality of the woman's safety options, including access to, and the realistic support offered by, services such as police, housing, childcare, safety planning and financial support should be presented. In essence, juries need evidence about what has been called social entrapment so they can understand how women's safety options are deeply intertwined with their degree of danger and therefore with the question of whether their response (of killing their abuser) was necessary based on reasonable grounds. We consider the types of evidence that may be important in helping juries understand the concept and particular circumstances of social entrapment, including the role of experts in this context.

\section{INTRODUCTION: USING A SOCIAL ENTRAPMENT PARADIGM TO SUPPORT SELF-DEFENCE}

It has been suggested that the two main paradigms used by decision-makers ${ }^{1}$ to understand facts involving intimate partner violence ('IPV') in the criminal justice context are a 'bad relationship with incidents of violence' paradigm and the 'battered woman syndrome'. ${ }^{2}$ Both understand IPV in terms of the incidents of

\footnotetext{
* Professor, Melbourne Law School, The University of Melbourne. We thank Sarah Kendall for assisting us to finalise this article.

** Associate Professor, Law School, The University of Western Australia.

*** Professor, Faculty of Law, The University Auckland.

1 We understand 'decision-makers' to include police, lawyers, judicial officers and jury members, as well as expert witnesses.

2 Julia Tolmie et al, 'Social Entrapment: A Realistic Understanding of the Criminal Offending of Primary Victims of Intimate Partner Violence' [2018] 2 New Zealand Law Review 181, 204, 206; Family Violence Death Review Committee, Social Entrapment: A Realistic Understanding of the Criminal Offending of Primary Victims of Intimate Partner Violence (Appendix to Article, 22 August 2018)
} 
physical violence that take place (even if acknowledged to be accompanied by other forms of abuse). Both paradigms make the assumption that in between these incidents the victim has effective safety options that she has chosen not to exercise (eg calling the police, getting a protection order or leaving the relationship). ${ }^{3}$ The difference between the two paradigms is that the 'bad relationship with incidents of violence' paradigm blames the victim for not exercising her safety options and thus the continuation of the violence, while a 'battered woman syndrome' framework excuses the victim for this on the basis that she had developed mental health issues as a result of the abuse. ${ }^{4}$

Both paradigms undercut a defendant's self-defence claims when her defensive actions are a response to a non-imminent threat, even where self-defence has been restated or amended to recognise that a person may need to defend themselves against non-imminent harm. ${ }^{5}$ When there is an assumption that effective safety options are available at all points where the victim is not actually under physical attack, it follows that her defensive violence cannot be understood as reasonable in self-defence unless she is actually under attack or threat of attack. ${ }^{6}$ Even in those circumstances, such an assumption makes it hard not to hold her partially accountable for waiting until things got to that point rather than exercising her safety options at a prior time.

Along with others, we contend that IPV is better understood as a form of social entrapment. ${ }^{7}$ Elsewhere Tarrant, Tolmie and Giudice have argued that the paradigm of social entrapment should be used to understand facts in homicide trials involving IPV where the victim of IPV ultimately kills her aggressor. ${ }^{8}$ This, Tarrant, Tolmie and Giudice have suggested, would provide juries with a fuller and more accurate picture of the nature of the abuse that the defendant was experiencing, and what she might reasonably have perceived her realistic safety options to be, at the time that she used defensive force against her abusive partner. ${ }^{9}$ A social entrapment model of IPV requires inquiry into three overlapping dimensions. ${ }^{10}$ First, what the coercive and controlling tactics of the predominant aggressor were and how they developed over time to close down the victim's space

('Social Entrapment Appendix'); Stella Tarrant, Julia Tolmie and George Giudice, Australia's National Research Organisation for Women's Safety, Transforming Legal Understandings of Intimate Partner Violence (Research Report No 03/2019, June 2019) 15-17.

3 See generally Tarrant, Tolmie and Giudice (n 2).

4 Tolmie et al (n 2) 204.

5 Tarrant, Tolmie and Giudice (n 2) 76-7.

6 We discuss this assumption and the basis for it later in the article: see below Part II.

7 See James Ptacek, Battered Women in the Courtroom: The Power of Judicial Responses (Northeastern University Press, 1999) 10; Tolmie et al (n 2); Family Violence Death Review Committee, Fifth Report: January 2014 to December 2015 (Report, February 2016) 39 ('Fifth Report'); Heather Douglas et al, 'Facts Seen and Unseen: Improving Justice Responses by Using a Social Entrapment Lens for Cases Involving Abused Women (as Offenders or Victims)' (2020) 32(4) Current Issues in Criminal Justice 488.

8 Tarrant, Tolmie and Giudice (n 2) 23.

9 Ibid 61.

10 Ibid 17 
for action. ${ }^{11}$ Second, what the responses of those who would be expected to be in a position to help were or would realistically be; and third, whether any intersecting structural inequities in the IPV victim's life circumstances affect the answers to these first two dimensions. ${ }^{12}$ The third dimension, in other words, refers to whether factors such as cultural norms around gender, experiences of precarity or disability or institutionalised racism supported or undermined the perpetrator's capacity to use coercive and controlling tactics and affected the actual or potential safety responses of those who might be in a position to help her. ${ }^{13}$

In this article we describe the types of evidence in each of the three dimensions outlined that might be required to ensure the jury understand the social entrapment experienced by the victim of IPV leading up to the killing. ${ }^{14}$ We also consider how expert evidence can be more effective in improving juries' (and judges') understanding of IPV so that their understanding better aligns with contemporary understandings of this form of violence.

\section{SELF-DEFENCE AND THE RESPONSIBILITY TO UNDERSTAND IPV ACCURATELY}

Tests for self-defence to homicide differ throughout Australia and New Zealand. However, they all use a test that, in different combinations, is partly subjective and partly objective. For example the self-defence test in the Criminal Code Act Compilation Act 1913 (WA) section 248(4) states:

A person's harmful act is done in self-defence if:

(a) the person believes the act is necessary to defend the person or another person from a harmful act, including a harmful act that is not imminent; and

(b) the person's harmful act is a reasonable response by the person in the circumstances as the person believes them to be; and

(c) there are reasonable grounds for those beliefs.

In essence, the state must disprove beyond reasonable doubt that the defendant believed on reasonable grounds that their defensive force was necessary in order for the defendant to avoid death or very serious harm. ${ }^{15}$

11 Ibid. See generally Nicola Sharp-Jeffs, Liz Kelly and Renate Klein, 'Long Journeys toward Freedom: The Relationship between Coercive Control and Space for Action' (2018) 24(2) Violence against Women 163.

12 Tarrant, Tolmie and Giudice (n 2) 17.

13 Ibid.

14 See generally Tolmie et al (n 2); Family Violence Death Review Committee, Fifth Report (n 6).

15 Thomas Crofts and Danielle Tyson, 'Homicide Law in Reform in Australia: Improving Access to Defences for Women Who Kill Their Abusers' (2014) 39(4) Monash Law Review 864, 877-80. See the test for self-defence under the common law: Zecevic v DPP (Vic) (1987) 162 CLR 645 (Wilson, Dawson and Toohey JJ): 'whether the accused believed on reasonable grounds that it was necessary in selfdefence to do what he [or she] did. If he [or she] had the belief and there were reasonable grounds for it, or if the jury is left in reasonable doubt as to the matter, then he [or she] is entitled to an acquittal' (at 661) and 'once the evidence discloses the possibility that the fatal act was done in self-defence' the burden shifts to the prosecution to disprove that the fatal act was not done in self-defence beyond reasonable doubt (at 657). 
Inaccurate conceptions of IPV are often used in criminal trials to understand the experience of a primary victim of IPV when she kills her abuser. ${ }^{16}$ This is a problem because it is an indignity for individuals to have their experiences misunderstood and misrepresented. However, the problem is deeper than this. Inaccurate understandings of IPV go to the heart of the trial because, if judges and jurors do not have the conceptual framework or the information and evidence they need to assess the violence that a defendant's claim of self-defence is based on, the law of self-defence cannot be properly applied. Thus, without an understanding of the social entrapment that a defendant faced, it is not possible to fairly assess their responses, which is required in an application of the law of self-defence.

Each person's experience of IPV is unique. ${ }^{17}$ Patterns of abusive behaviours are tailored to a particular victim and also determined by the responses to those behaviours by everyone around the victim and perpetrator, including responses by powerful social institutions. ${ }^{18}$ Furthermore, each victim is situated differently in wider social structures of support or marginalisation. Nevertheless, although each individual's experience of IPV is different, it is clear that violence embedded in the intimate access one person has to another over time in conditions that permit, or encourage, domination, is a distinctly different form of violence from the form of violence usually understood to underpin a claim of self-defence, generally violence that arises in instances of physical altercation (a 'fight'). ${ }^{19}$ That IPV is a specific form of violence, which must be understood differently to other kinds of violence, has long been recognised in critiques and commentary on the law of selfdefence, ${ }^{20}$ and underpins legislative and judicial reforms in this context. ${ }^{21}$ However, the paradigm shift required so that this knowledge structures the application of self-defence laws to the facts at trial has not occurred, or has occurred exceptionally. ${ }^{22}$

16 See, eg, Tarrant, Tolmie and Giudice (n 2) 8, citing Julia Quilter, 'Reframing the Rape Trial: Insights from Critical Theory about the Limitations of Legislative Reform' (2011) 35(1) Australian Feminist Law Journal 23.

17 Although we recognise many aspects and experiences of IPV are similar. See Judith Herman, 'Justice from the Victim's Perspective' (2005) 11(5) Violence against Women 571.

18 Evan Stark, Coercive Control: How Men Entrap Women in Personal Life (Oxford University Press, 2007) 285; Ptacek (n 7) 10; Tolmie et al (n 2); Family Violence Death Review Committee, Fifth Report (n 7).

19 William Hawkins, A Treatise of the Pleas of the Crown (Elizabeth Nutt and R Gosling, 1716-1721) ch 29; Tarrant, Tolmie and Giudice (n 2) 64-73, 78-82.

20 See, eg, Elizabeth Sheehy, 'Expert Evidence on Coercive Control in Support of Self-Defence: The Trial of Theresa Craig' (2018) 18(1) Criminology \& Criminal Justice 100; Brenda Midson, 'Coercive Control and Criminal Responsibility: Victims Who Kill Their Abusers' (2016) 27(4) Criminal Law Forum 417.

21 See, eg, Criminal Code Act Compilation Act 1913 (WA) s 248(4); Crimes Act 1958 (Vic) s 322J; Evidence Act 1977 (Qld) s 132B. See also Osland v The Queen (1998) 197 CLR 316, 337 [56] (Gaudron and Gummow JJ). On the application of the Evidence Act 1977 (Q1d) s 132B, see Rebecca Campbell 'Domestic Relationship Evidence in Queensland: An Analysis of a Misunderstood Provision' (2019) 42(2) University of New South Wales Law Journal 430.

22 Elizabeth Sheehy, Julie Stubbs and Julia Tolmie, 'Defences to Homicide for Battered Women: A Comparative Analysis of Laws in Australia, Canada and New Zealand' (2012) 34(3) Sydney Law Review 467, 492. See also Elizabeth Sheehy, Julie Stubbs and Julia Tolmie, 'Securing Just Outcomes for Battered Women Charged with Homicide: Analysing Defence Lawyering in $R v$ Falls' (2014) 38(2) Melbourne 
The misunderstanding of IPV by decision-makers can be seen as part of a wider, whole-community misunderstanding of this form of violence. ${ }^{23}$ However, how IPV is understood is a particular problem in criminal trials because it is central to liability and therefore to just outcomes for victims of IPV. Understandings about IPV in the criminal trial are lagging behind, and failing to utilise readily available research about IPV. ${ }^{24}$

In this article we consider how evidence of social entrapment may be introduced, but more particularly how expert evidence can be more effective in improving judges' and juries' understanding of IPV. Whilst we see no option for now other than to admit expert evidence to assist a jury in these kinds of trials, it is important to note that, in fact, this legal mechanism is ill-suited to the broader problem we are discussing in this article. The admission of expert evidence is a legal mechanism designed for a different kind of problem. Evidence from experts assists juries to determine adjudicative facts that are in issue where there is a contest between the parties (the accused and the state) about the existence of a particular fact. For example, expert evidence can assist in resolving the question of whether the pattern of blood stains in evidence could have been made by a blow wielded with a particular force.

However, where the problem concerns the premises on which the state has built its case (in this context, how IPV is understood), the problem is not really one about adjudicative facts between parties. Rather it is about the legitimacy of assumed knowledge that is the foundation of decision-making related to the charge and the prosecution's approach to the case. The understanding of IPV which underpins the prosecution case is also likely to underpin judicial directions and jury decision-making. Therefore, if there is an error in this respect, it occurs prior to, or beyond, the scope of a particular trial. Rathus and others refer to this kind of knowledge as 'social framework evidence', ${ }^{25}$ Hamer and Edmond refer to it as 'exogenous knowledge'. ${ }^{26}$

Criminal justice mechanisms that directly address this kind of problem include education and training for judges and other decision-makers outside of the trial

University Law Review 666 ('Securing Just Outcomes'); Silva v The Queen [2016] NSWCCA 284; $R v$ Stephen [No 6] [2018] NSWSC 243.

23 See, eg, Kim Webster et al, Australia's National Research Organisation for Women's Safety, Australians Attitudes to Violence against Women and Gender Equality: Findings from the 2017 National Community Attitudes towards Violence against Women Survey (NCAS) (Research Report No 03/2018, 2018) 8; Royal Commission into Family Violence: Report and Recommendations (Report No 132, March 2016) vol 1, 17 ('Royal Commission into Family Violence').

24 See, eg, Family Violence Death Review Committee, Fifth Report (n 7) 119; Tarrant, Tolmie and Giudice (n 2).

25 See Zoe Rathus, 'A Call for Clarity in the Use of Social Science Research in Family Law DecisionMaking' (2012) 26(2) Australian Journal of Family Law 81, 88, 113; Heather Douglas, 'Social Framework Evidence: Its Interpretation and Application in Victoria and Beyond' in Kate Fitz-Gibbon and Arie Freiberg (eds), Homicide Law Reform in Victoria: Retrospective and Prospects (Federation Press, 2015) 94-109 ('Social Framework Evidence').

26 David Hamer and Gary Edmond, 'Judicial Notice: Beyond Adversarialism and into the Exogenous Zone' (2016) 25(3) Griffith Law Review 291. 
context, ${ }^{27}$ and access by judicial officers to research findings or established social knowledge through judicial notice. ${ }^{28}$ 'No case' defence submissions can also address the problem of an inadequate knowledge-base on the part of decisionmakers; it can be argued the state has failed to produce sufficient evidence to meet its onus and standard of proof due to its case having been structured by reference to frameworks of knowledge incapable of producing relevant evidence necessary for proof. ${ }^{29}$

Thus, relying on expert evidence to address decision-makers' inaccurate understandings of the nature of IPV is problematic. The expert evidence 'solution' reinforces the assumption that the issue is a contest between the two parties, as opposed to the trial proceeding on the basis of inaccurate, but collectively held, misconceptions about the social phenomenon that is at the heart of the trial decision. These misconceptions remove responsibility from the state to disprove self-defence beyond reasonable doubt. ${ }^{30}$ Assuming expert evidence is a solution to this problem:

- fails to shift responsibility back to the state to disprove self-defence beyond reasonable doubt;

- places on the defence a responsibility to do more than raise a reasonable doubt that there was, for example, a defence of self defence available to the defendant on the facts;

- obscures the deficiency of the state's case and ultimately the state's failure to disprove self-defence;

- obscures the problem as one about the credibility of witnesses, and ultimately the credibility of the accused. ${ }^{31}$

When the expert testimony is challenging the framework that is used to think about an issue in circumstances where decision-makers do not realise that their conceptual frameworks are incorrect and when they are therefore listening to that expert testimony through their existing frameworks, they may fail to understand the testimony or grasp why it is necessary in the first place.

Despite these concerns, in Part IV we consider how the courts should understand the nature of IPV within the framework of expert evidence. We take this pragmatic approach because, although imperfect, it is a mechanism that is currently available to introduce relevant knowledge for the assistance of judges and juries and it has potential to provide a more informed basis for decision making.

27 See, eg, Australasian Institute of Judicial Administration, 'Purpose and Limitations', National Domestic and Family Violence Bench Book (Web Page, June 2020) [1] <https://dfvbenchbook.aija.org.au/>.

28 See generally Rathus (n 25); Hamer and Edmond (n 26). See also Fenton v Police [2014] SASC 167, [40] (Blue J).

29 See, eg, $R v$ Stephen [No 3$]$ [2018] NSWSC 168, [8]-[20] (Button J); $R v$ Stephen [No 6] [2018] NSWSC 243, [3]-[9] (Button J); Judicial College of Victoria, 'Victorian Criminal Proceedings Manual' (Manual, 20 March 2019) [5.7]. <https://www.judicialcollege.vic.edu.au/eManuals/VCPM/index.htm\#27507.htm>.

30 Tarrant, Tolmie and Giudice (n 2) 10.

31 See generally Gary Edmond, David Hamer and Emma Cunliffe, 'A Little Ignorance Is a Dangerous Thing: Engaging with Exogenous Knowledge Not Adduced by the Parties' (2016) 25(3) Griffith Law Review 383, 403-4. 


\section{THE EVIDENCE NEEDED TO SUPPORT A SELF-DEFENCE CASE BASED ON SOCIAL ENTRAPMENT}

In this Part we describe the three dimensions of social entrapment and consider the evidence needed to support each one. Improved understanding of the evidence needed to support a self-defence case based on social entrapment is important at all levels of the criminal justice decsion-making process, from police investigation (for example, what evidence is collected) to how the prosecution case will be framed, how lawyers will prepare the defence and how judges direct the jury. While we touch on how expert evidence may be important to support the three dimensions in this Part, we expand our discussion of expert evidence in Part IV.

\section{A Dimension One: The Coercive and Controlling Behaviours of the Predominant Aggressor and Their Impact on the Victim over Time}

The first dimension of social entrapment involves an inquiry into the abuse tactics used by the predominant aggressor, as well as how they impacted on the primary victim, ${ }^{32}$ over time. Evan Stark suggests that IPV is not an assault crime - in other words, it is not about the infliction of physical violence per se, but rather, he argues, it is an attack on the victim's personhood. ${ }^{33}$ The United Kingdom ('UK') Home Office describes IPV as 'a purposeful pattern of behaviour which takes place over time in order for one individual to exert power, control or coercion over another'. ${ }^{34}$

What needs to be understood is whether and how the perpetrator of IPV has established control over the primary victim by undermining her independence through isolating her, depriving her of basic survival resources, exploiting her, and micro-regulating her. ${ }^{35}$ It also requires understanding whether and how the perpetrator has used direct coercion to punish the victim for resisting or to force compliance, including using violence (often chronic 'low level' violence and sexual violence) and intimidation - threatening her and what is most dear to her, placing her under surveillance and degrading her.

Abuse tactics are developed over time and targetted to the particular victim based on what works on her, and so tactics will be fact specific and will take effect cumulatively. ${ }^{36}$ For example, the predominant aggressor may not use physical violence until he has managed to isolate the victim from her family and friends or

32 The terms 'predominant aggressor' and 'primary victim' are used by the New Zealand Family Violence Death Review Committee to describe which parties, in the overall relationship history, are the abuser and victim, regardless of who is the offender in the death event: Family Violence Death Review Committee, Fifth Report (n 7) 119.

33 Stark (n 18) 13, 223, 380-2.

34 Home Office (UK), Controlling or Coercive Behaviour in an Intimate or Family Relationship: Statutory Guidance Framework (December 2015) 3 [10] (emphasis omitted).

35 See generally Stark (n 18) 274.

36 For an attempt to illustrate how social entrapment operates in relation to one particular case see Tarrant, Tolmie and Giudice (n 2) 23-40. 
until she is irrevocably committed to the relationship (for example, when she becomes pregnant).

Sometimes power dynamics are evident from the beginning of the relationship, which can look more like a hostage-taking than two parties freely entering an intimate partnership. For example, where the predominant aggressor who is older and gang-affiliated 'picks' the victim; ${ }^{37}$ a predominant aggressor who within a short time of meeting the victim persuades her to engage in sexual behaviours that (in the circumstances that they are in) commit her to him but not him to her; ${ }^{38}$ or a predominant aggressor forcing the victim to marry him under duress. ${ }^{39}$ The same dynamics can be evident in the resumption or continuation of relationships. For example, women who do not wish to have sex with their 'partner' and are living apart from their partner being considered within their communities or by institutional authorities to be 'in a relationship', ${ }^{40}$ presumably because their partner has not yet relinquished them; ${ }^{41}$ and predominant aggressors pursuing victims who attempt to 'separate' and simply reinstating the relationship by moving back in with them.

Isolating behaviours can include smashing phones or engaging in unacceptable behaviour so that it is easier for the victim to let other relationships lapse or not leave the house or which alienates others. Such behaviours can include him being the 'nice guy' with others and portraying her as the 'crazy one'; persuading her to move to locations away from those communities and individuals who are most invested in her; or forcing her to engage in behaviours that infringe her core values or degrade her so that she cannot disclose what is happening because of shame. Isolating behaviours may include bullying or manipulating her into engaging in illegal behaviours, making her vulnerable to arrest if she seeks help from authorities, or insisting that she only socialise with him. Sexual abuse has the effect of isolation through shame ${ }^{42}$ and accrues benefits for perpetrators through the societal reluctance to inquire about it or acknowledge it. ${ }^{43}$

$37 R v$ Chase [2016] NZHC 2665, [115], [198], [221]-[222] (Katz J).

38 Western Australia v Liyanage [2016] WASC 12; Western Australia v Liyanage [2016] WASCSR 31; Liyanage v Western Australia (2017) 51 WAR 359 ('Liyanage'). See also Tarrant, Tolmie and Giudice (n 2) 23 .

39 See the facts of $R v$ Wang [1990] 2 NZLR 529, as discussed in Lexie Kirkconnell-Kawana and Alarna Sharratt, 'Commentary on $R v$ Wang: Finding a Plausible and Credible Narrative of Self-Defence' in Elisabeth McDonald et al (eds), Feminist Judgements of Aotearoa New Zealand Te Rino: A TwoStranded Rope (Hart Publishing, 2017) 495.

40 See, eg, in the context of social security and assumptions about a continuing relationship and the couple rule: Lyndal Sleep, Australia's National Research Organisation for Women's Safety, Domestic Violence, Social Security and the Couple Rule (Research Report No 04/2019, July 2019).

$41 \quad R v$ Wihongi [2012] 1 NZLR 775, 775.

42 Jill Messing, Jonel Thaller and Meredith Bagwell, 'Factors Related to Sexual Abuse and Forced Sex in a Sample of Women Experiencing Police-Involved Intimate Partner Violence’ (2014) 39(3) Health \& Social Work 181, 188. 
Deprivation and exploitation can include controlling finances ${ }^{44}$ putting all property ownership in his name, undertaking illegal activities in her name, limiting her access to transport, and depriving her of sleep, food, specialist support or medical services that she needs. The destruction of her rental accommodation can leave her and her children ineligible for other accommodation and without anywhere to live. Sabotaging her efforts to become independent can include undermining her attempts to educate herself, upskill, obtain or retain employment; sabotaging birth control so that she becomes pregnant; ${ }^{45}$ sabotaging her attempts to access treatment for her addiction issues; and deliberately getting her addicted, or fostering her dependence on him for drugs or alcohol.

Micro-regulation according to gender stereotypes may include: rules about how she dresses; what opinions she expresses; when she socialises and with whom; what or how she cooks; whether she pursues employment or study; what contraception she uses; how she parents; how long she has to complete chores and how she performs them; and how much money she is allowed to spend and on what. It can involve lecturing her about how she can improve as his partner or on other topics that she may be tested on afterwards. As Stark points out, these rules are about conditioning the primary victim to obey the predominant aggressor's commands without regard to their substance. ${ }^{46}$ Compliance may seem to guarantee physical safety, but the rules are constantly revised so that it is not possible to comply and the victim is left in a state of constant anxiety. ${ }^{47}$

The predominant aggressor uses violence or threats of violence to establish the costs of non-compliance and create fear in the victim. ${ }^{48}$ Violence will often be low level chronic violence that has a cumulative intensity for the victim - along with other coercive and controlling behaviours. It exhausts and overwhelms her so that it becomes easier, and maybe safer, for her to comply than resist. High level violence used infrequently can make threats about the consequences of future noncompliance credible. It is important when documenting the violence to capture the retaliatory aspect, which includes the predominant aggressor's response to (inevitable and ongoing) acts of resistance by the victim.

Intimidatory tactics include threats to hurt or destroy the victim and/or what is most dear to her (including parents, children or her relationship with her children) if she fails to comply. They may include threats to have the children removed by child protection services or threats to report the victim to child protection services. ${ }^{49}$ Threats can include suicide or murder suicide by the predominant aggressor. Intimidation may include surveillance so that she knows that he is

44 Jozica Kutin, Roslyn Russell and Mike Reid, 'Economic Abuse between Intimate Partners in Australia: Prevalence, Health Status, Disability and Financial Stress' (2017) 41(3) Australian and New Zealand Journal of Public Health 269, 269.

45 Heather Douglas and Kath Kerr, 'Domestic and Family Violence, Reproductive Coercion and the Role for Law' (2018) 26(2) Journal of Law and Medicine 341, 343-4.

$46 \quad$ Stark (n 18) 281.

47 Ibid 286. See generally Paige Sweet, 'The Sociology of Gaslighting' (2019) 84(5) American Sociological Review 851.

$48 \quad$ Stark (n 18) 242.

49 See Heather Douglas and Emma Fell, 'Malicious Reports of Child Maltreatment as Coercive Control: Mothers and Domestic and Family Violence' (2020) 35(8) Journal of Family Violence 827. 
always everywhere, ${ }^{50}$ potentially monitoring her. It can include monitoring her social media, bank accounts, phone and text messages; stalking her; obliging her to account for her movements; (secretly) tracking or recording her; and using her phone to initiate conversations with her friends designed to ascertain whether she has been unfaithful to him. Degradation includes forcing her to engage in behaviours that infringe her core values (or those of her community) and which therefore shame and/or degrade her, including sexual violence (eg, anal rape when the victim dislikes anal penetration).

\section{B Dimension One: Proving Coercive and Control}

Evidence about the tactics of coercive control, how they unfolded over time and how they impacted on the specific victim must usually come from the victim's own testimony because the behaviours only become visible in the micro-details of everyday life and in the weight of their repetition over time. Many will be unwitnessed or, if witnessed, may not be intelligible as abuse to those around them. Whilst defendants who are articulate, persuasive, have clear recall and have begun to move through their healing process and make sense of what happened to them may be able to describe these behaviours in detail and explain how they unfolded over time, this will be more difficult for defendants who have brain injury, ${ }_{51}$ trauma responses, and are intimidated by the courtroom and cross-examination. ${ }^{52}$

Evidence corroborating the primary victim's testimony ${ }^{53}$ could come from those in the couple's community as to their observations in relation to a range of things (her changed behaviour, injuries, how their relationship with her or her employment was affected by his behaviour) or their own personal experiences of the predominant aggressor's intimidatory, violent or controlling behaviours. Bank accounts, diary entries, text messages, records of phone, social media and internet activities, including determining who has passwords to which accounts and who does not, can potentially be useful. ${ }^{54}$ If the couple have any large debts, it may be important to note whose name they are registered in. Records from medical health professionals (dentists, doctors, midwives, mental health, addiction services and services around the termination of pregnancy), and the police may be helpful, as may be the predominant aggressor's past police contact and criminal record. The primary victim's records may demonstrate what she was consulting for, whether she was able to attend appointments alone, and whether there were patterns of cancellation or frequent visits. ${ }^{55}$ Children's school records (including attendance

50 See Bridget Harris 'Spacelessness, Spatiality and Intimate Partner Violence: Technology-Facilitated Abuse, Stalking and Justice' in Kate Fitz-Gibbon et al (eds), Intimate Partner Violence, Risk and Security: Securing Women's Lives in a Global World (Routledge, 2018) 52, 57.

51 See generally Brain Injury Australia, The Prevalence of Acquired Brain Injury among Victims and Perpetrators of Family Violence (Report, April 2018).

52 Herman (n 17) 574.

53 See Home Office (UK) (n 34) 12-13.

54 Ibid.

55 Jodie Valpied and Kelsey Hegarty, 'Intimate Partner Abuse: Identifying, Caring for and Helping Women in Healthcare Settings' (2015) 11(1) Women's Health 51, 54. 
records), health records and observations from their teachers may also be helpful. ${ }^{56}$ Work and income records may show advances for food, car repairs and necessities.

For example, in $R v$ Falls ('Falls') ${ }^{57}$ where Susan Falls was acquitted of the murder of her abusive partner, her mobile phone demonstrated that she had no friends listed in her contacts, whilst her abusive partner's phone revealed that he had many. Associates in Falls, ${ }^{58}$ such as the person who rented a storage unit to the couple, testified that she rarely spoke and her demeanour in her partner's presence was subdued. In Liyanage $v$ The State of Western Australia ('Liyanage') $)^{59}$ where Charmari Liyanage was found guilty of the manslaughter of her abusive partner, her associates testified that she would not answer the phone when they called and on one occasion she apologised later, explaining that her husband did not like her to socialise without him. ${ }^{60}$ One person testified in Liyanage's trial that the defendant told her where she was going with her husband and asked her to pretend to bump into them so that they could spend time together. ${ }^{61}$ Sometimes the expectations the predominant aggressor has of the primary victim are recorded in the form of written agreements, as was the case in Liyanage. ${ }^{62}$

If the physical violence is hidden, as it frequently is, then evidence of concealing clothing that is inappropriate for the climate or activity and/or heavy makeup or sunglasses that are worn inside can provide indirect evidence of injury in the form of coverups. In Falls this evidence came from hairdressers and teachers at the school the defendant's children went to; ${ }^{63}$ in Liyanage it came from associates who worked at the same hospital. ${ }^{64}$ Other people's experiences of the predominant aggressor's intimidating or violent behaviour are helpful. In Falls, one of the deceased's friends was able to testify as to his personal experiences of the deceased's retaliatory violence in response to a breach of his instructions. ${ }^{65}$

We argue that expert testimony may be admitted to provide a comprehensive and intelligible account of the primary victim's experiences of abuse if their own account is disjointed or fragmented. The expert can frame the abusive behaviour so that it is understood as a pattern of behaviours which are strategic and retaliatory in nature and have a cumulative intensity in their impact, rather than as a series of violent incidents. The expert can explain that the primary victim's ongoing

56 See Family Violence Death Review Committee, Fifth Report (n 7) 55; Family Violence Death Review Committee, Social Entrapment Appendix (n 2) 4.

57 Transcript of Proceedings, $R v$ Falls, Coupe, Cummings-Creed and Hoare (Supreme Court of Queensland, 928/2007, Applegarth J, 3 June 2010) 15.

58 Sheehy, Stubbs and Tolmie, 'Securing Just Outcomes' (n 22) 681 n 68, citing Transcript of Proceedings, $R v$ Falls (Supreme Court of Queensland, 928/2007, Applegarth J, 24 May 2010) 32-3 (G J Cummings, Leisel Deanne Bourne). See also $R v$ Chase [2016] NZHC 2665, [86] (Katz J), in which associates testified that the complainant's 'personality changed drastically' after she entered the relationship. She became 'quiet, withdrawn, reserved and would not talk much'.

59 Liyanage (2017) 51 WAR 359.

60 Tarrant, Tolmie and Giudice (n 2) 25, 35.

61 Ibid 25

62 Ibid 27.

63 Sheehy, Stubbs and Tolmie, 'Securing Just Outcomes' (n 22) 684 n 87, citing Transcript of Proceedings, $R v$ Falls (Supreme Court of Queensland, 928/2007, Applegarth J, 1 June 2010) 13 (J R Hunter).

64 Tarrant, Tolmie and Giudice (n 2) 35.

65 Sheehy, Stubbs and Tolmie, 'Securing Just Outcomes’ (n 22) 681. 
resistance to the primary aggressor is not evidence of her empowerment or negotiating power. Expert testimony can rehabilitate the primary victim's credibility if this is necessary by explaining how 'experiences of victimisation and trauma and the dynamics of shame, guilt, fear, psychological avoidance (dissociation, emotional numbing, repression) and grief can affect a [primary victim's] presentation at each stage of the [criminal justice] process' ${ }^{66}$ Trauma and head injury can affect recall, including about the order of events, and make her emotional effect flat when recalling the abuse. ${ }^{67}$ Expert evidence in this context may be provided by a health professional such as a medical specialist (including a psychologist or psychiatrist), ${ }^{68}$ by a social worker ${ }^{69}$ or an academic. $^{70}$

\section{Dimension Two: Explaining the Family Violence Safety Response}

The second dimension of social entrapment is to realistically examine the safety options available to the defendant in her circumstances, rather than simply assuming that calling the police/getting a protection order/'leaving' the relationship would have readily addressed the abuse and ensured she was protected from serious harm or death.

The first set of questions concerns the responses of her community to any observations of abuse, disclosures by the primary victim or predominant aggressor and/or any help-seeking behaviours that occurred. Allan Wade points out that negative social responses can be as harmful to the victim as the original assault and may determine whether the victim discloses again. ${ }^{71}$

The second set of questions is directed at any barriers to accessing services, how services had responded to help-seeking in the past, and what services were realistically able to offer her in the circumstances (and her children or other extended family members if these people were also under threat). ${ }^{72}$

For example, a victim's experience of engagement with police, or her community's past engagement with the police, is an important factor in

66 Family Violence Death Review Committee, Social Entrapment Appendix (n 2) 7. See also Family Violence Death Review Committee, Fifth Report (n 7), 37.

67 See $R v$ Ney [2008] QSC 597 [2]-[3]. Ney, an Aboriginal woman, was convicted of manslaughter after killing her male partner. The sentencing judge accepted that 'the relationship was marked by violence' and noted the effects of trauma on 'mental and psycho-social processes'.

68 Stephen v DPP (NSW) [2018] NSWSC 1018, [28] (Button J); R v Craig (2011) 276 OAC 117, [26] (The Court). See also 'Women Who Kill Violent Men', Insight (SBS, 2020) $<$ https://www.sbs.com.au/news/insight/tvepisode/women-who-kill-violent-men >.

69 See Sheehy, Stubbs and Tolmie, 'Securing Just Outcomes' (n 22) 697, citing Transcript of Proceedings, $R$ $v$ Gadd (Supreme Court of Queensland, 355/1994, Moynihan J, 30 March 1995) 189 (J Jerrard, Catherine Ann Miller).

$70 \quad R v$ Challen [2019] EWCA Crim 916, [37] (Lady Hallett); DPP v Williams [2014] VSC 304, [33] (Hollingworth J).

71 Social Chefs Dagarna (socialchefsdagarna), 'Socialchefsdagarna 2014 Göteborg, Allan Wade om [sic] Violence, Resistance and Power in Language' (YouTube, 10 November 2014) 00:02:40-00:03:04 $<$ https://www.youtube.com/watch?v=TZjXZbKQ4nc>.

72 Family Violence Death Review Committee, Social Entrapment Appendix (n 2) 8-9. See generally Family Violence Death Review Committee, Fifth Report (n 7). 
determining whether the victim will call the police or call them again. ${ }^{73}$ Further, the predominant aggressor's involvement with criminal networks or activities or his gang associations may make it difficult for her to access a wide range of services, including the police. If she lives rurally or in an area without full services, or does not have affordable transport or child care or a phone or credit on her phone, then this may make access difficult. It is important when assessing her past engagement to understand that any help seeking or disclosures will be taking place within the context of her entrapment. She may, for example, seek medical care for injuries but fail to disclose how they occurred or call the police but be uncooperative when they arrive - in this instance the arrival of the police may have served its immediate purpose but being seen to be cooperative with them would be unsafe.

Crucial to consider is whether the service responses that are available to her are capable of matching the operation and harm of the IPV she is experiencing. As we have noted, IPV is ongoing and designed to close down any help-seeking by the primary victim (dimension one), meaning that an effective safety response must have the capacity to protect the victim from future abuse, including acts of retaliation once the perpetrator has been put on notice that the victim has disclosed the abuse to others. If the response of an agency is likely to be confined to a reaction to past events, whilst leaving him with unrestricted access to her; or to provide her with a court order that must be breached before she can enforce it; or to provide her with temporary accomodation that she must eventually leave; or a safety plan that requires her to initiate any safety response, then her available safety responses are unlikely to be effective in providing safety from a dangerous family violence offender.

\section{Dimension Two: Sources of Evidence about the Family Violence Safety Response}

Evidence from the primary victim and from others in the community as to what they knew and what they did in response will be important in demonstrating the community safety response or lack of it. Primary victims and others in their community will be able to address a range of questions. Do others in the couple's family/social networks passively or actively support his abuse of her? Were other people intimidated by him? Did others fail to call police or other services because they were worried about their own safety? Were others 'at a loss' about what to do about his behaviour? Did others assume/hope that she was the person who could/should best 'handle' him? ${ }^{74}$ Were there any safe people in her community and what actions could they be relied upon to take? Did they intervene in the past and, if so, what happened?

73 Betty Jo Barrett et al, 'Pathways to Police Contact for Spousal Violence Survivors: The Role of Individual and Neighborhood Factors in Survivors' Reporting Behaviors' (2021) Journal of Interpersonal Violence 36(1)-(2) 636.

74 In Gore v Western Australia [2017] WASCA 163, a health worker asked Ms Gore two days before the killing to take the deceased back into her home because she was the one best able to 'look after' him: Annabel Hennessey, 'Health Failings Cost Two Lives?' The West Australian (Perth, 3 September 2019), $10-11$. 
The primary victim may be able to testify as to what agencies were able to do for her in the past, or others in a similar situation, when she/they did reach out for help. Did they give her advice as to what she needed to do to keep herself or her children safe? Did they take any action that contained his abusive behaviour or made her safer? If she disclosed one form of abuse did they inquire into, or provide an opportunity for her to disclose about other forms of abuse, including sexual abuse? Did their response compromise her safety further? Did they support her and her children to gain access to housing and food that they needed? Did they consider the risk of his retaliation when planning their responses? If she had contact with services such as mental health and addiction services, did they respond to her safety needs?

Agency records or testimony from professionals might be helpful in corroborating her account as to what happened in the past or her perceptions as to what would have occurred if she had attempted to use their services. For example, expert factual evidence from a police officer who is a family violence specialist as to what the police could realistically offer the victim by way of safety responses had she engaged with their services - including what they could provide her family if they were also under threat (including anyone who lived overseas) - could be significant in disrupting the assumption that calling the police would have guaranteed her safety. Expert factual evidence from an experienced refuge manager as to what their services were able to provide someone in her circumstances might also be helpful.

Evidence of contact the predominant aggressor had with social services, health or drug and alcohol services and police may also be helpful in demonstrating what services did in response to their knowledge of violence or the risk of violence.

In Falls, ${ }^{75}$ a police officer who had tried to assist the defendant in the past, but had failed, testified. The police officer said that they believed that the predominant aggressor would kill the primary victim. ${ }^{76}$ In Liyanage, the primary victim had not contacted the police. She testified that she thought a likely outcome from contacting the police was that she would be left alone to deal with her abuser. ${ }^{77}$ The police would interview him and he would simply deny the abuse and they would be unlikely to find evidence to support the fact that it had taken place. ${ }^{78}$ Of course the police interview would have alerted him to the fact that she had breached his instructions to not disclose the abuse. ${ }^{79}$ Even if the police did take action and he was fined or spent time in prison, once he got out he would pursue her and her family. She said she could go into hiding but she was unable to take

75 Transcript of Proceedings, $R v$ Falls, Coupe, Cummings-Creed and Hoare (Supreme Court of Queensland, 928/2007, Applegarth J, 3 June 2010).

76 Sheehy, Stubbs and Tolmie, 'Securing Just Outcomes' (n 22) 682.

77 She said that her abuser would deny the violence and the police would be unlikely to find evidence, meaning that ' $[\mathrm{t}]$ hey might not do anything about it. And, anyway, I have to go back to the home at the end of the day': Transcript of Proceedings, Western Australia v Liyanage (Supreme Court of Western Australia, Hall J, 12 January 2016) 1037.

78 Ibid.

79 Tarrant, Tolmie and Giudice (n 2) 36-7. 
all of her family into hiding. ${ }^{80}$ In Liyanage, the prosecution asserted that the reasonable thing to do was to call the police but produced no evidence to prove that her understanding of what would happen if she did so were not realistic. ${ }^{81}$

Expert testimony about the likely response of agencies could be provided by someone with detailed working knowledge of the systemic response to IPV. Although this form of expertise is unusual, it exists in a death review committee specialist or member, if the committee's death review process involves access to original agency records in order to conduct a systemic analysis of the actual functioning of the family violence safety system. Such an expert can state to the jury that separation does not stop the abuse if statutory services are not able to provide effective safety responses to post-separation abuse. Someone from the Victorian Royal Commission on Family Violence, ${ }^{82}$ who has heard extensive evidence from specialists across the family violence safety system, might have the necessary systems knowledge, as might a social worker with a high level of experience at a grass roots level in assisting victims to navigate the family violence safety system. An academic or researcher who has evaluated relevant services may be able to provide expert testimony. Alternatively, this expertise could be provided by an academic who has collated and analysed the experiences of large numbers of survivors who have attempted to engage with family violence services as to service users' experience of those services. ${ }^{83}$

\section{E Dimension Three: Structural Intersectionality}

It is harder to provide a general summary of the manner in which intersectional inequities may support the predominant aggressor's coercive control or undermine the safety responses of those in a position to help. Such matters might include the primary victim's age and vulnerability; history in state care; immigration status; cultural positioning ${ }^{84}$ experiences of precarity; access to housing, benefits, affordable childcare, transport and services; number and age of dependent children; experiences of institutionalised racism and so on. Women on insecure visas or without visas may reasonably fear deportation without their Australianborn children, leaving their children in danger with the primary aggressor, should they seek help. ${ }^{85}$

80 Transcript of Proceedings, Western Australia v Liyanage (Supreme Court of Western Australia, Hall J, 12 January 2016) 1051.

81 Tarrant, Tolmie and Giudice (n 2) 50, 81-2.

82 Royal Commission into Family Violence (n 23).

83 See Liz Kelly, Nicola Sharp and Renate Klein, Solace Women's Aid, Finding the Costs of Freedom: How Women and Children Rebuild Their Lives After Violence (Report, 2014) 9. Most studied women reported that statutory services pressured them to leave the relationship but gave them no support to do so or afterwards: at 5 . A further $90 \%$ of women who left were abused after leaving.

84 In Liyanage (2017) 51 WAR 349, the Court held that such evidence may be admissible: 'Suppose, for example, that there were particular cultural barriers in Sri Lankan society to a wife leaving her husband' (at 398 [164]). See also Dell Marie Butler, 'Holding Back the Battered Woman: Western Australia v Liyanage [2016] WASC 12' (2016) 41(1) University of Western Australia Law Review 321, 341.

85 Marie Segrave, Temporary Migration and Family Violence: An Analysis of Victimisation, Vulnerability and Support (Report, 2017) 9-10. 
Similarly, Aboriginal and Torres Strait Islander women may not seek police help because they know incarceration is dangerous for Aboriginal men, ${ }^{86}$ or they may reasonably fear arrest and incarceration themselves, leaving their children vulnerable and in danger, should they seek help. ${ }^{87}$ In Gore $v$ Western Australia ('Gore'), ${ }^{88}$ Ms Gore, an Aboriginal woman, killed her intimate partner, an Aboriginal man who suffered severe mental health problems, including psychotic episodes. She was, and remains convicted of murder, but was released from prison after serving just over four years of her life sentence after her history of family violence was publicised and the State Attorney-General intervened, recommending her early release. ${ }^{89}$ On occasions Ms Gore did not call the police when her partner was violent because there were no services within a distance that could possibly have assisted her or because she did not want her partner to go to jail. ${ }^{90}$ His mental health problems manifested many years earlier during his three month imprisonment for traffic offences. ${ }^{91}$ Ms Gore was relied on heavily by those around her and by government health services to support her partner both before and after they 'separated', despite her being the person he directed his violence at. Two days before the killing she was asked by a community health worker to take him in again because she was the person best able to look after him. ${ }^{92}$

Indigenous women can also experience barriers in seeking help from services, such as cultural barriers, racial biases and stereotyping. ${ }^{93}$ Women may have to use services with environments and practices that they are not comfortable with because they do not have access to culturally appropriate services. If the service setting is experienced by the victim as unsafe this will impact on any disclosures made to that service. ${ }^{94}$ Montesanti and Thurston point out that women not only experience direct physical harm from their partners but also through 'the injuries that come from the bureaucracies within institutions that do not respond to their needs and instead disrespect and mistreat them and further exacerbate their

86 Harry Blagg, Nicole Bluett-Boyd and Emma Williams, Australia's National Research Organisation for Women's Safety, Innovative Models in Addressing Violence Against Indigenous Women: State of Knowledge Paper (Research Report No 08/2015, August 2015) 13.

87 Heather Douglas and Robin Fitzgerald, 'The Domestic Violence Protection Order System as Entry to the Criminal Justice System for Aboriginal and Torres Strait Islander People' (2018) 7(3) International Journal for Crime, Justice and Social Democracy 41, 48-9.

88 [2017] WASCA 163. In that case, Damien Jones (the deceased) was characterised by the Court as Ms Gore's former partner despite him coming and going from her home, living with her and her children: at [1], [21] (Mazza, Mitchell and Beech JA).

89 Annabel Hennessey, 'Justice for Jody', The West Australian (Perth, 27 September 2019).

90 Transcript of Proceedings, The State of Western Australia v Gore (Supreme Court of Western Australia, No 327 of 2015, Hall J, 18 August 2015) 252-3, 379.

91 Ibid 379-80.

92 Hennessey, 'Justice for Jody' (n 89).

93 See generally Carla A Houkamau, 'What You See Can’t Hurt You: How Do Stereotyping, Implicit Bias and Stereotype Threat Affect Māori Health?' (2016) 5(2) MAI Journal 124.

94 Cultural safety includes putting in place systems and processes that support cultural integrity and safety from a physical, mental, emotional or spiritual perspective: Victoria Hovane, White Privilege and the Fiction of Colour Blindness: Implications for Best Practice Standards for Aboriginal Victims of Family Violence' (Summer 2006/07) Australian Domestic and Family Violence Clearinghouse 10. '[R]espect for cultural and linguistic diversity must occur at a structural and systemic level' in order to achieve appropriate responses: at 11. 
marginalization'.$^{95}$ A recent New Zealand report on Māori wāhine trying to keep themselves and their tamariki safe in unsafe relationships highlights that the response of those services charged with helping such women can be far worse for the women than the violence that they experience from their male partners. ${ }^{96}$

\section{F Dimension Three: Establishing Structural Inequality}

Structural inequality can be addressed by the primary victim's testimony and through the testimony of others in her community. ${ }^{97}$ Expert testimony on cultural norms around gender, marriage and help-seeking, or experiences of systemic racism in the systemic safety response (and to counter negative readings of the defendant's addiction issues and violent resistance) and/or the nature of precarity could also be helpful, depending on the facts. ${ }^{98}$ Community elders, ${ }^{99}$ anthropologists, ${ }^{100}$ socio-linguists ${ }^{101}$ and others with specific cultural expertise of relevant communities ${ }^{102}$ could be called to give expert evidence about some of these matters, as can researchers who have conducted empirical studies interviewing particular communities of women about the unique structural barriers they experience in seeking help. ${ }^{103}$

\section{EXPERT EVIDENCE}

In Part III we identified the range of evidence and sources of evidence, including experts, that may be helpful in establishing social entrapment. In this part we focus on the role of expert evidence.

All Australian jurisdictions except Queensland, Western Australia and South Australia are now governed by uniform evidence law ('Uniform Evidence Act' or ' $U E A$ '). ${ }^{104}$ The common law, supplemented by state Evidence Acts, ${ }^{105}$ applies in those three remaining states. The principles relating to expert evidence or

95 Stephanie Rose Montesanti and Wilfreda E Thurston, 'Mapping the Role of Structural and Interpersonal Violence in the Lives of Women: Implications for Public Health Interventions and Policy' (2015) 15(100) BioMed Central Women's Health 1, 11

96 Denise Wilson et al, Wāhine Māori: Keeping Safe in Unsafe Relationships (Report, 28 November 2019) 30 .

97 See, eg, Gore [2017] WASCA 163; Hennessey, 'Justice for Jody’ (n 89).

98 See generally Anthony Good, 'Cultural Evidence in Courts of Law' (2008) 14 (Special Issue) The Journal of the Royal Anthropological Institute 47.

99 For sentencing cases, see Heather Douglas and Mark Finnane, Indigenous Crime and Settler Law: White Sovereignty after Empire (Palgrave Macmillan, 2012) 167-70.

100 Walden $v$ Hensler (1987) 163 CLR 561, 564 (Brennan J).

$101 R v$ Kina [1993] QCA 480, 34-5 (Fitzgerald P and Davies JA).

102 Yildiz v The Queen (1983) 11 A Crim R 115, 119 (Young CJ); Liyanage (2017) 51 WAR 359, 398 [164] (The Court).

103 See, eg, Wilson et al (n 96): this report provides an example of such evidence.

104 Each jurisdiction has enacted model legislation: Evidence Act 1995 (Cth); Evidence Act 2011 (ACT); Evidence Act 1995 (NSW); Evidence (National Uniform Legislation) Act 2011 (NT); Evidence Act 2001 (Tas); Evidence Act 2008 (Vic). This legislation is referred to as the 'Uniform Evidence Act' or 'UEA'. Evidence Act 1977 (Qld); Evidence Act 1929 (SA); Evidence Act 1906 (WA). 
specialised knowledge as it is referred to in the $U E A$ are broadly the same, though there are some differences. ${ }^{106}$

\section{A Relevance}

All evidence, including expert evidence or specialised knowledge, must be relevant to a fact in issue in the proceeding in order to be admissible. ${ }^{107}$ In the context of this article the fact in issue we focus on is the nature of the threat that the primary victim of IPV faced from the deceased and whether there were reasonably available safety alternatives open to them other than killing the primary aggressor. Under the $U E A$, material is legally relevant if it 'could rationally affect (directly or indirectly) the assessment of the probability of the existence of a fact in issue'. ${ }^{108}$ At common law, material is legally relevant if it is logically relevant and not 'too remote'. ${ }^{109}$

An expert witness may give evidence about facts peculiar to the particular case or of facts of general application to the evidence in the trial. ${ }^{110}$ Expert evidence or specialised knowledge may be directly relevant to the individual accused's (or another witness's) conduct or beliefs, for example, a psychological or other assessment of the accused; or indirectly relevant, for example framework evidence may provide an evidence-based foundation on which a fact-finder can determine what the accused's beliefs were or assess their conduct by reference to a rationally determined standard. For example, Lee J, in Ward $v$ Western Australia ${ }^{111}$ said: '[e]xpert anthropological evidence serves to provide a framework within which the primary evidence of Aboriginal witnesses can be considered'. ${ }^{112}$ Expert evidence of IPV as social entrapment will often be framework evidence, relevant in this second way. This was recognised in the recent New Zealand case, $R v$ Ruddelle ${ }^{113}$ where evidence of social entrapment was accepted to be relevant and admissible. ${ }^{114}$

However, expert evidence about typical responses to sexual assault, sought to be relied on by the prosecution as framework evidence, was rejected by the Victorian Court of Appeal on the basis that the evidence was insufficiently connected to the specific facts of the case and therefore irrelevant. ${ }^{115}$ In Jacobs ( $a$

106 Section 322M of the Crimes Act 1958 (Vic), s 132B of Evidence Act 1977 (Qld) and s 39A of the Evidence Act 1906 (WA) provide for the admissibility of evidence about 'family violence' (Victoria and Western Australia) and 'domestic violence' (Qld). Our discussion is limited to general laws of evidence. UEA ss 55, 79; Smith v The Queen (2001) 206 CLR 650, 653 [6] (Gleeson CJ, Gaudron, Gummow and Hayne JJ).

108 UEA s 55; Smith v The Queen (2001) 206 CLR 650, 654 [7] (Gleeson CJ, Gaudron, Gummow and Hayne $\mathrm{JJ})$.

109 Hollingham v Head (1858) 140 ER 1135, 1136 (Willes J); $R$ v Stephenson [1976] VR 376, 381 (The Court).

$110 P Q v$ Australian Red Cross Society [1992] 1 VR 19, 34-6 (McGarvie J).

111 (1998) 159 ALR 483.

112 Ibid 531, cited in Risk v Northern Territory [2006] FCA 404, [464] (Mansfield J).

113 [2019] NZHC 2973.

114 Ibid [4], [8]-[13] (outlining the nature of the evidence) and [18] (noting that all parties accepted that it was admissible) (Gordon J).

115 Jacobs (a Pseudonym) v The Queen [2019] VSCA 285, [132]-[133] (Priest, Kaye JJA and Kennedy AJA). 
Pseudonym) $v$ The Queen ('Jacobs'), ${ }^{116}$ expert testimony was given by a psychologist about the reasons a person may not report a sexual assault. ${ }^{117}$ The evidence was found to have been wrongly admitted because the reasons given by the complainant for not reporting the assault until she did, did not correspond with a number of the reasons shown in the expert testimony to be typical. ${ }^{118}$ For example, because the complainant's reasons for not reporting did not include mistrust of the police in her area (though she mistrusted the police in her home country, Colombia), expert evidence to the effect that it is not uncommon for victims of sexual assault to be reluctant to report because of prior experiences with police that have lead to mistrust was held to be irrelevant. ${ }^{119}$ In $R v$ Lang ('Lang'), ${ }^{120}$ expert evidence about the social context in which a death occurred was held to be irrelevant and wrongly admitted. ${ }^{121}$ There the fact in issue was whether a woman committed suicide by stabbing herself in the abdomen or was murdered by her intimate partner. Evidence introduced by the victim's psychiatrist of the very low rate of stabbing suicides by Australian women was held to have no probative value because it measured suicides against all Australian women with no comparative statistical evidence about the rate of homicides against all Australian women. ${ }^{122}$

Both Jacobs and Lang concerned expert evidence for the prosecution and so the courts were also concerned with prejudice to the accused from the admission of the evidence. But framework evidence sought to be introduced by a defendant has been rejected because it had insufficient connection to facts of the case. In Liyanage, social framework evidence (about the level of risk of homicide the primary victim faced when she killed her abuser) was found to be irrelevant because the primary victim did not know of the expert's risk assessment tools. ${ }^{123}$

In these cases the courts isolated specific components of the framework evidence and found there was insufficient connection between those specific claims and very particular facts in issue. Arguably this begins to alter the function of evidence introduced as framework evidence, which is designed to provide a context within which determinations about facts can be made. Moreover, expert evidence of IPV as social entrapment in the context of self-defence is distinguishable from cases such as Jacobs and Lang because it is relevant to questions about the 'reasonableness' of an accused's responses rather than whether particular facts existed. When assessing whether a person acted reasonably, a jury is not determining 'what happened' but evaluating the person's actions, and such an evaluation necessarily requires a framework external to the accused by which to judge. The relevance of evidence of IPV as social entrapment is its capacity to provide that evaluative framework.

116 [2019] VSCA 285.

117 Ibid [4] (Priest, Kaye JJA and Kennedy AJA).

118 Ibid [135], [139] (Priest and Kaye JJA and Kennedy AJA).

119 Ibid [112], [141]-[142] (Priest and Kaye JJA and Kennedy AJA).

$120 R v$ Lang [2019] QCA 289.

121 Ibid [42]-[43] (The Court).

122 Ibid [38]-[42] (The Court).

123 Liyanage (2017) 51 WAR 359, 389-90 [125]-[129] (The Court). 
Therefore the purpose of expert evidence of IPV as social entrapment must be clear. Evidence of IPV understood as social entrapment is relevant because it provides a jury with a rational basis (the best available knowledge base) for determining questions about the particular accused's conduct and beliefs. Specifically, in determining self-defence, where juries have to make an assessment about whether the prosecution have proved that the accused's behaviour was not reasonable in the circumstances, such evidence helps juries to understand the circumstances. This will mean that the jury's need for this assistance (ie, that it does not already possess that knowledge-base) must be established.

There is a tension between general knowledge and facts specific to a case. Framework evidence is not generally adduced to determine disputed primary facts but an expert on social entrapment will need to make it clear how this expertise can be applied in the particular case. The jury should be informed about how the expert evidence they are hearing might assist them. This could be done by the trial judge but may also be incorporated in the expert's evidence. An expert would usually explain that the three dimensions of social entrapment provide a structure for determining the questions that a fact-finder needs to ask rather than providing answers to particular questions of fact, although the expert will need to refer to facts of the case.

\section{B Specialised Knowledge}

Expert evidence, or specialised knowledge, once it is determined to be relevant, may be of fact or opinion. Although characterising evidence as fact or opinion can be difficult, ${ }^{124}$ if evidence is specialised knowledge of fact and no opinion is provided based on those facts, the rules of evidence relating to opinion evidence do not apply. ${ }^{125}$ This is important in the context we are discussing because much of the expert evidence that will support a claim of social entrapment will be evidence of facts only, gained by training and experience working in the field of family violence. Unless a witness draws inferences by applying their expertise to the facts of the particular accused, they are not providing opinion evidence and an application for the admission of such evidence on the basis that it is relevant factual material should be considered by defence counsel. Examples of evidence that has been found by courts not to be opinion evidence include "evidence of personal experience and observations over a very lengthy period in a highly specialised market'. ${ }^{26}$ 'Evidence from an anthropologist will "often be direct evidence of the anthropologist's observations", ${ }^{127}$ not opinion evidence, and observations of an experienced truck driver about the behaviour of large vehicles may not be opinion evidence. ${ }^{128}$ Similarly, evidence from, for example, a

124 John W Strong et al (eds), McCormick on Evidence (West Publishing, $4^{\text {th }}$ ed, 1992) 18, quoted in Kenneth $\mathrm{J}$ Arenson and Mirko Bagaric, Rules of Evidence in Australia: Text \& Cases (LexisNexis Butterworths, $2^{\text {nd }}$ ed, 2007) 504. See Stephen Odgers, Uniform Evidence Law (Lawbook Company, 14 ${ }^{\text {th }}$ ed, 2019) 548. Birla Nifty Pty Ltd v International Mining Industry Underwriters Ltd (2014) 47 WAR 522, 538 [70] (McLure P).

127 Odgers (n 106) 521, quoting Bodney v Bennell (2008) 167 FCR 84, 108 [94] (The Court). Weal v Bottom (1966) 40 ALJR 436, 438 (Barwick CJ). 
witness with experience gained through access to family violence death reviews can provide relevant specialised factual knowledge about the dynamics of IPV and the systemic responses they observed from agencies. They may give evidence of themes and patterns in their observations of the histories of IPV and agency responses through systematic reviews of numerous IPV deaths. This evidence should be considered evidence of fact, not opinion.

Drawing inferences about the accused's particular circumstances based on specialised knowledge, or expert evidence about the overarching framework of social entrapment and the need to inquire into each of the three dimensions, may amount to opinion evidence. Accordingly, we now consider the admissibility of expert opinion evidence.

At common law and under the $U E A$, opinion evidence aimed at proving or disproving a fact in issue is inadmissible, ${ }^{129}$ unless it comes within a recognised exception to this general rule. Expert opinion (at common law) ${ }^{130}$ and opinion based on specialised knowledge (section 79 of the UEA) are exceptions to the general rule. Opinion evidence rules at common law and under the UEA are broadly similar, with some differences. Section 79(1) of the UEA provides:

If a person has specialised knowledge based on the person's training, study or experience, the opinion rule does not apply to evidence of an opinion of that person that is wholly or substantially based on that knowledge.

Therefore, two key aspects to the admissibility of expert opinion evidence are as follows. ${ }^{131}$ First, the opinion must be based on 'specialised knowledge'. Here the specialised knowledge will be about the three dimensions of social entrapment. ${ }^{132}$ Second, the opinion must be wholly or substantially based on the relevant specialised knowledge. We consider these two requirements in the following sections.

\section{An Opinion Based on 'Specialised Knowledge'}

A person must have specialised knowledge based on training, study or experience. ${ }^{133}$ Neither 'knowledge' nor 'specialised' knowledge is defined in the $U E A$. Courts have interpreted these requirements (consistently with the common law) to involve two overlapping components. First, the knowledge must be capable of assisting the trier of fact. At common law the 'common knowledge' rule requires expert opinion evidence to go beyond what ordinary jurors are capable of discerning for themselves. ${ }^{134}$ Section 80 of the UEA abolished the common law

129 UEA s 76; Hollington v F Hewthorn and Co Ltd [1943] 1 KB 587, 595 (Goddard LJ).

130 Clark v Ryan (1960) 103 CLR 486, 491 (Dixon CJ).

131 See also David Robertson and Charles Gregory, 'Admissibility of Expert Evidence' [2018] (Spring) Bar News 82,82 .

132 This has been referred to as social framework evidence. See, eg, Julie Stubbs and Julia Tolmie, 'Falling Short of the Challenge? A Comparative Assessment of the Australian Use of Expert Evidence on the Battered Woman Syndrome' (1999) 23(3) Melbourne University Law Review 709; Douglas, 'Social Framework Evidence' (n 25).

133 UEA s 79; Weal v Bottom (1966) 40 ALJR 436, 438 (Barwick CJ); Clark v Ryan (1960) 108 CLR 486, 490 (Dixon CJ).

134 Transport Publishing Co Pty Ltd v Literature Board of Review (1956) 99 CLR 111, 119 (Dixon CJ, Kitto $\mathrm{J}$ and Taylor $\mathrm{J}$ ). 
rule but a requirement remains that the proposed knowledge assist the fact-finder. It is not 'specialised' knowledge if it provides nothing further than the fact-finder already has access to. ${ }^{135}$ The Australian High Court has held that specialised knowledge "is knowledge which is outside that of persons who have not by training, study or experience acquired an understanding of the subject matter' ${ }^{136}$

Courts have accepted that expert evidence about 'abnormal' human behaviour could be of assistance to a jury and rejected evidence on the basis that 'normal' human behaviour is the exclusive province of the jury. ${ }^{137}$ Traditionally the focus was the 'normal'/'abnormal' psychology of an accused but in Murphy $v$ The Queen, ${ }^{138}$ the High Court recognised the difficulty in determining what was 'normal', ${ }^{139}$ and found that expert assistance concerning a person's capacities to receive and process information could be of assistance to a lay jury in determining whether those distinctive capacities were the result of innate psychological characteristics or environmental factors. ${ }^{140}$ In $R v$ Falconer, ${ }^{141}$ in which Mrs Falconer was charged with the murder of her abusive husband, the High Court found that expert opinion about the responses of an ordinary mind to extraordinary circumstances could assist a jury.

However, as discussed, expert evidence about social frameworks is not relevant because it explains unusual behaviour but because it facilitates an accurate assessment of behaviour. It assists in revealing the normality or ordinariness of an individual's conduct and beliefs. In this context courts have utilised the idea of 'counterintuition'. Expert evidence is admissible if it can counter what would otherwise be assumed to be unreasonable or inexplicable behaviour. One of the bases for admission of battered woman syndrome evidence was that it would assist fact finders to understand the behaviour of an abused woman, which would otherwise appear odd or perverse. ${ }^{142}$

The principle of 'counterintuition' may in some ways be useful in arguments about how expert evidence of social entrapment could assist a jury but it is ultimately not a good fit. This is because it tends to construct an individual's conduct as 'intuitively' odd until it is rehabilitated with special information. This line of reasoning leads, for example, to evidence of battered woman's syndrome (or post-traumatic stress disorder) being taken as a 'diagnosis' of the victim of IPV, helpful to understand her 'unusual' behaviour but at the same time suggesting a lack of reason. ${ }^{143}$ As social framework evidence, evidence about IPV as social

135 This can be analysed as a question of relevance. If the opinion of a so called expert does not render more or less probable the existence of a fact in issue, then it is not relevant: Smith v The Queen (2001) 206 CLR 650, 654 [7], 655 [11] (Gleeson CJ, Gaudron, Gummow and Hayne JJ). Honeysett v The Queen (2014) 253 CLR 122, 131 [23] (French CJ, Kiefel, Bell, Gageler and Keane JJ).

137 Transport Publishing Co Pty Ltd v Literature Board of Review (1956) 99 CLR 111, 119 (Dixon CJ, Kitto $\mathrm{J}$ and Taylor J).

138 (1989) 167 CLR 94.

139 Ibid 111 (Mason CJ and Toohey J)

140 Ibid 126-7 (Deane J)

141 (1990) 171 CLR 30.

142 Barbara Ann Hocking, 'Limited (and Gendered?) Concessions to Human Frailty: Frightened Women, Angry Men and the Law of Provocation' (1999) 6(1) Psychiatry, Psychology and the Law 57, 63. See Tarrant, Tolmie and Giudice (n 2) 16-17. 
entrapment assists the jury in a fundamentally different way. It concerns (predominantly) behaviours and beliefs of those other than the primary victim of IPV. For example, understanding IPV as a form of coercion and control is a way of understanding the patterns of behaviour of the deceased and the second and third dimensions of a social entrapment framework concern others' responses to the primary victim's and the perpetrator's behaviours and broader societal circumstances in which the victim is placed. Moreover, the purpose of social entrapment evidence is to address potential errors of perception on the part of the jury, not errors or ill-conceived behaviours of the accused. Whether a primary victim's belief that her response was necessary was not based on reasonable grounds is the outcome of the inquiry, not the starting point.

The second requirement of 'specialised knowledge' is that the proposed evidence has a sufficiently stable or validated source or foundation. That is, it must be 'knowledge' and not mere belief or speculation. At common law an expert opinion must have been drawn from a 'recognised field of expertise', that is, recognised as a sufficiently established view even if not unanimously accepted, by those working in the discipline, profession or skilled community in which the proposed expertise is based. ${ }^{144}$ A different line of authority favours a 'reliability' test. Neither 'test' is included in section 79 of the UEA but standards of validity are embedded in the requirement that an opinion is based on 'knowledge'.

Rules relating to fields of expertise or reliability of proposed specialised knowledge have been developed predominantly in relation to the 'hard' sciences. ${ }^{145}$ However, there is no doubt that other systems of knowledge, including those in the social sciences, are admissible as specialised knowledge. In Risk v Northern Territory, Mansfield J wrote:

$[\mathrm{T}]$ here are 'great practical differences' between experts' reports from different disciplines ... Science and mathematics are exact disciplines, whereas anthropology, humanity, much of economics and history are not. There is a longer list which could be created. In most if not all disciplines, opinion is formed by reasoning drawn from a group of 'facts'. The facts may be drawn from a scientific experiment, historical documents or a series of conversations held with a native title claimant group ... Some ['facts'] are complex and themselves involve judgment. In the realm of expert evidence, the primary data upon which an opinion is based may comprise a mixture of primary and more complex facts. The opinion may then be further based upon an interpretation (sometimes requiring expertise) of those facts and that stage may require an exercise of judgment, sometimes fine judgement, by the person concerned. ${ }^{146}$

We argue that IPV as social entrapment is an area of specialised knowledge, as accepted in the New Zealand High Court in $R v$ Ruddelle. ${ }^{147}$ There are a number of developments that point to increasing acceptance that social entrapment, or at least the discrete dimensions of social entrapment, are recognised as subjects of specialised knowledge that ordinary jurors cannot be expected to comprehend without assistance.

144 See generally $R v$ Runjanjic (1991) 56 SASR 114.

145 In Clark v Ryan (1960) 108 CLR 486, McTiernan J and Dixon CJ respectively refer to 'scientific evidence' and DNA profiling as examples: at 491, 496.

146 [2006] FCA 404, [467]-[468] (citations omitted).

147 [2019] NZHC 2973. 


\section{Assisting the Fact-Finder: Social Entrapment}

Wild $\mathrm{J}$ in $R v$ Martin $^{148}$ considered that a 'lucid description' of a particular psychological concept would 'materially assist the jury'. ${ }^{149}$ The test he posed in arriving at this point was whether '[i]f ten passers-by were stopped on Victoria Avenue in Wanganui and asked to give an explanation of' the relevant phenomenon, could many do so? ${ }^{150}$ His conclusion was that not 'many, if any, could do so'. ${ }^{151}$

One could pose a similar test here - if ten passers-by were stopped in an Australian street and asked to describe how the tactics of coercive and controlling behaviour worked in an intimate relationship and what the essential nature of IPV was, it is likely that many would be unable to do so - although they might be able to talk about acts of violence or identify that IPV included psychological, financial and sexual abuse. If they were asked whether, if a victim was prepared to seek help, effective help was available to her, it is likely that most would assume that this was so.

Underlining the community's lack of understanding of the dynamics of coercive control and its assumption that leaving will lead to safety are the findings of a 2017 community survey undertaken in Australia. ${ }^{152}$ In particular, nearly one in three Australians believe that a female victim who chooses not to leave is responsible for the abuse continuing. ${ }^{153}$ Underpinning this judgment is an assumption that leaving is always possible and will provide safety. ${ }^{154}$

The 2017 community survey also found that there is a decline in the number of Australians who understand that men are more likely than women to perpetrate domestic violence and that one third of respondents thought it was natural for a man to want to appear to be in control of his partner in front of his friends. ${ }^{155}$ These assumptions are at odds with contemporary knowledge of IPV.

Judicial officers have been willing to admit expert psychiatric and psychological evidence of mental processes internal to the 'battered woman' through expert evidence of 'battered woman syndrome' as a way to explain why women stay in abusive relationships. ${ }^{156}$ But there has been resistance to the need for expert evidence about the dimensions of social entrapment, eg, coercive control, the systemic family violence safety response and the victim's cultural and broader social context. Chin and Crozier argue that courts routinely downplay the power of external factors and place too much weight on human psychological processes and psychological disorders when seeking explanations of people's life

\footnotetext{
148 [2004] 3 NZLR 69.

149 Ibid 75 [29] (Wild J).

150 Ibid.

151 Ibid 75 [28].

152 Webster et al (n 23).

153 Ibid 81

154 Webster et al (n 23) 83. See also Jason Chin, 'Pre-recorded Expert Evidence in Intimate Partner Violence Cases' (2020) 32(4) Current Issues in Criminal Justice 458; Tolmie et al (n 2) 206.

155 Australia's National Research Organisation for Women's Safety, Are We There Yet? Australian's Attitudes towards Violence against Women and Gender Equality (Summary Report, 2018) 7, 9. See, eg, Osland v The Queen (1998) 197 CLR 316.
} 
circumstances. ${ }^{157}$ It is thus no surprise that psychological evidence of 'battered woman syndrome' or a battered woman's perception of her situation - rather than evidence about the real danger and (socially constructed) trap she is in - has been admitted. ${ }^{158}$ For example, in Liyanage, an expert psychiatrist was permitted to give evidence of his opinion that Dr Liyanage had 'stayed' with her husband because of her 'personality' traits and disposition resulting from her 'upbringing'. ${ }^{159}$

Further support for the proposition that social entrapment is specialist knowledge that is necessary to assist a fact-finder comes from increasing understanding of the significant impact that unconscious biases have on how individuals perceive the world. Individuals, including judges and juries, routinely use mental shortcuts; psychologists refer to these as 'heuristics', and these effect the way decisions are made. ${ }^{160}$ In the context of understanding the dynamic of IPV and social entrapment a number of mental shortcuts might be made. ${ }^{161}$ For example, a juror who has a friend who left a bad relationship with apparent ease and had no further contact with her ex-partner may assume this is the norm as this is the information on the topic most easy for him to retrieve from memory (availability bias). People also overestimate their ability to have been able to predict events that occurred in the past and believe others, ${ }^{162}$ like a primary victim, should have also been able to do this. For example, a juror may believe that they would have realised that a person was abusive before finding themselves too far into a committed relationship with them and would have put steps in place to ensure that they escaped the violence before it became unendurable (hindsight bias). ${ }^{163}$ White, middle class and well-resourced people who experience mainstream services as attentive to their needs may assume that their experiences are shared by others. Chin and Crozier observe that judges may exclude experts, assuming that jurors are fully equipped to understand the unconscious and situational forces operating on them, and this may be a mistake. ${ }^{164}$ There are many well-recognised biases and assumptions that underpin and exacerbate misunderstandings about how IPV operates; ${ }^{165}$ these should be counteracted with expert evidence.

157 Jason M Chin and William E Crozier, 'Rethinking the Ken Through the Lens of Psychological Science' (2018) 55(3) Osgoode Hall Law Journal 625.

158 See, eg, Osland v The Queen (1998) 197 CLR 316. See generally The University of Queensland, 'Case Studies: Battered Women Syndrome', Australian Feminist Judgments Project (Web Page, 2 July 2018) $<$ https://law.uq.edu.au/afjp-case-studies $>$.

159 Tarrant, Tolmie and Giudice (n 2) 42-3, 88.

160 Chris Guthrie, Jeffrey J Rachlinski and Andrew J Wistrich, 'Judging by Heuristic: Cognitive Illusions in Judicial Decision Making' (2002) 86(1) Judicature 44.

161 For example, a juror may have read that average police attendance times are within 10 minutes of being called and may 'anchor' his understanding that police attend within 10 minutes (anchoring bias): ibid 456.

162 Ibid 47.

163 See generally ibid 47-8; of course such assessments also fail to factor in the extreme terror that the predominant aggressor may have deliberately instilled in the victim.

164 Chin and Crozier (n 157) 627.

165 See Heather Douglas, 'Policing Domestic and Family Violence' (2019) 8(2) International Journal of Crime, Justice and Social Democracy 31, 33-6, 43. 


\section{A Recognised 'Field of Study'/Reliability: Social Entrapment}

An indication that social entrapment is an area of specialist expertise is its introduction into professional courses of study. In 2019 new standards were introduced in social work and counselling training throughout Australia that include core curriculum on power, oppression and exploitation in relationships. ${ }^{166}$

In relation to dimension one, a number of legal bodies and courts have already recognised that understanding IPV as coercive control is specialised knowledge. In the UK, police officers and prosecutors receive specialised training about coercive control. ${ }^{167}$ A sociologist and forensic social worker, Evan Stark, has provided expert evidence about coercive control which has been admitted in courts in Canada and in the UK. ${ }^{168}$ In a recent case in the UK, expert testimony about the dynamics of coercive control from academic Professor Marianne Hester was admitted. ${ }^{169}$

Dimension two, the family violence safety response, may also be the subject of expert testimony. This aspect of social entrapment has received less attention from the courts than coercive control. As noted earlier, where evidence of selfdefence is raised during the trial, the Crown must exclude it beyond reasonable doubt. This means that the prosecution must prove beyond a reasonable doubt that the primary victim had other ways of preserving herself from death or very serious harm (including any ongoing torture that she was experiencing), than killing the primary aggressor. For example, depending on the facts, the Crown must prove that contacting the police would have provided the primary victim with effective safety in her circumstances.

In $R v$ Barrett,${ }^{170}$ the Saskatchewan Court of Appeal held the Crown to this burden. The judge pointed out that it was for the Crown to prove that, had the female defendant in that case contacted child protection services, they would have been able to provide an immediate and effective safety response for her children. ${ }^{171}$ She argued that her actions in forcibly removing the children from their father were taken in defence of those children, ${ }^{172}$ while the Crown invited the court to assume that she could have contacted child protection agencies if she was concerned about her children's safety. ${ }^{173}$

In relation to dimension three (structural inequality), there are a number of criminal cases, including petitions for pardon and sentencing decisions, where expert evidence of cultural context and cultural norms has been recognised as specialist expertise by the courts. For example in $R v$ Kina, a sociolinguist's expertise in Aboriginal people's ways of communicating was recognised as

166 Australian Association of Social Workers, Australian Social Work Education and Accreditation Standards (Standards, August 2019) 25.

167 'Controlling or Coercive Behaviour in an Intimate or Family Relationship', Crown Prosecution Service (Web Page, 30 June 2017) <https://www.cps.gov.uk/legal-guidance/controlling-or-coercive-behaviourintimate-or-family-relationship $>$.

$169 R v$ Challen [2019] EWCA Crim 916.

170 (2019) SKCA 6.

171 See, eg, ibid [29]-[30], [71], [74] (Leurer JA).

172 Ibid [22].

173 Ibid [29]. 
specialist knowledge. ${ }^{174}$ This expertise was relevant to understanding why the Aboriginal defendant did not disclose sensitive information in response to direct questions from police, lawyers and others. ${ }^{175}$ In Walden v Hensler, an Aboriginal person defended his right to take bush resources as an 'honest claim of right' when charged with offences under the Fauna Conservation Act 1974 (Qld). ${ }^{176}$ An anthroplogist's expertise about Aboriginal culture was recognised as specialist expertise. ${ }^{177}$ In sentencing hearings, cultural expertise is often recognised in cases involving the sentencing of Aboriginal people in Australia ${ }^{178}$ and Māori in New Zealand. ${ }^{179}$ In Yildiz $v$ The Queen the Court of Criminal Appeal of Victoria held that expertise about cultural values in the Turkish Australian community was admissible in a murder trial to explain Turkish attitudes to homosexuality. ${ }^{180} \mathrm{In}$ Liyanage, the Western Australian Court of Appeal accepted that expert evidence of a defendant's culture, which may not otherwise be known to the jury would be admissible: '[s] uppose, for example, that there were particular cultural barriers in Sri Lankan society to a wife leaving her husband'. ${ }^{181}$ We suggest that these examples open up the possiblity for specialist expertise to be admitted about cultural norms around gender, marriage and help-seeking, or experiences of systemic racism in the safety response to IPV.

In New Zealand, Rachel Smith, an independent family violence consultant who had conducted death reviews for the New Zealand Family Violence Death Review Committee over a seven-year period, was permitted to give evidence about all three dimensions of social entrapment in the homicide/self-defence case of $R v$ Ruddelle. ${ }^{182}$

\section{The Opinion Must Be Wholly or Substantially Based on the Person's Specialised Knowledge}

Section 79 of the UEA requires that an expert witness's opinion be wholly or substantially based on their specialised knowledge, and this is consistent with the common law. ${ }^{183}$ For an opinion to be based on specialised knowledge, there must be a demonstrable, and demonstrated, connection between the opinion and an expert's specific expertise. ${ }^{184}$ A generalised statement of expertise is insufficient. ${ }^{185}$ If a witness's opinion is not based on their actual expertise, their conclusions amount merely to 'subjective impression[s]' or speculation. ${ }^{186} \mathrm{In}$

\footnotetext{
174 [1993] QCA 480, 34-5 (Fitzgerald P and Davies JA).

175 Ibid 34 (Fitzgerald $P$ and Davies JA).

176 (1987) 163 CLR 561.

177 Ibid 564 (Brennan J).

178 See Douglas and Finnane (n 99) 165-70.

179 See, eg, Solicitor-General v Heta [2019] 2 NZLR 241.

180 (1983) 11 A Crim R 115, 119 (Young CJ).

181 (2017) 51 WAR 359, 398 [164] (The Court).

182 [2019] NZHC 2973; Anna Leask, 'Domestic Violence Expert Urges Murder Trial Jury to View "Panoramic Perspective", Not Single Moment', New Zealand Herald (online, 17 February 2020). HG v The Queen (1999) 197 CLR 414, 427-8 [39]-[40] (Gleeson CJ).

Ibid [41]-[42] (Gleeson CJ). 
Honeysett $v$ The Queen, the High Court held that the opinion of an anatomy expert about the similarity between the head shapes of the accused and the offender was not based on the witness's specialised knowledge of anatomy but on his nonspecialised observations. ${ }^{187}$

While psychologists and psychiatrists have been recognised by the courts as experts who have specialist knowledge about the dynamics of IPV ${ }^{188}$ they may not be the best experts to give this testimony. They are certainly not qualified to give evidence on the limitations of the current 'family violence safety system' or structural inequality. ${ }^{189}$ Psychologists study the human mind and psychiatrists are primarily trained to diagnose, treat and prevent mental, emotional and behavioural disorders. ${ }^{190}$ Thus both of these professional groups are focused on the internal workings of a person's mind.

Social workers and counsellors, by way of contrast, are trained to work with people in their social context and to assist them to address external issues. ${ }^{191}$ Social workers and counsellors operate on the frontline response to IPV and are often employed in services such as shelters, helplines and support programs. ${ }^{192}$ In these frontline roles they routinely assist women trying to survive in relationships with violent offenders, trying to address the violence of their partner, and having to navigate complex systems (eg, police, housing, courts, social security) which often do not have effective ways of containing their (ex) partner's abusive behaviour in the process. They are well placed to address the question of what lawful protections primary victims have in trying to address the violence of their partners and expartners and, through their training and experience, to give expert evidence about social entrapment. ${ }^{193}$

We would suggest that expert testimony directed at understanding patterns of abusive behaviour in their social context, including the systemic responses to IPV, would generally be appropriately provided by a social scientist or an experienced social worker rather than a psychologist or psychiatrist. By way of contrast, expert evidence about the defendant's presentation in court or their inability to remember details as a result of brain injury, might better come from a mental health or trauma expert, such as a psychiatrist or psychologist.

Expert testimony from a social science perspective was admitted in the Queensland case of $R v$ Gadd. ${ }^{194}$ In Department of Public Prosecutions (Vic) $v$ Williams, expert evidence of the general nature of family violence from an

187 Ibid. See also Dasreef Pty Ltd v Hawchar [2011] HCA 21.

188 Stubbs and Tolmie (n 132) 712, 730.

189 Although the evidence of a psychiatrist about the family safety system was found to be admissible in DPP (Vic) v Bracken [No 12] [2014] VSC 351 [4], [10], [17] (Maxwell P).

190 Butler (n 84) 326.

191 See 'Careers in Social Work', Australian Association of Social Workers (Web Page, 2020) $<$ https://www.aasw.asn.au/careers-study/careers-in-social-work-2/careers-in-social-work>. Ibid.

193 Stubbs and Tolmie (n 132) 731.

194 Transcript of Proceedings, $R v$ Gadd (Supreme Court of Queensland, Moynihan J, 27 March 1995) 18998, cited in Stubbs and Tolmie (n 132) 731. 
academic with research expertise in family violence was admitted at trial. ${ }^{195}$ Evidence about the nature of IPV within a social science framework has also been provided by social workers or specialist IPV workers in proceedings relating to homicide convictions other than at trial. For example, social workers gave expert evidence in $R v$ Kina in a petition for pardon, ${ }^{196}$ and in $R v$ Yeoman in sentencing proceedings. ${ }^{197}$ However, the Western Australian Court of Appeal in Liyanage, the only court of appeal to have dealt with this form of IPV evidence, held that expert evidence about IPV from a social worker based on risk assessment tools was inadmissible at trial to support a primary victim's self-defence claims in response to homicide charges. ${ }^{198}$ The Court limited expert testimony to that which is provided by a psychologist or psychiatrist on 'the psychological impact of prolonged exposure to domestic violence'. ${ }^{199}$

By way of contrast, the testimony of Evan Stark, whose work on coercive control we have drawn on (above) in providing an account of the nature of IPV, has been accepted at trial in the United States and in Canada. In 2008, in $R v$ Craig $^{200}$ a Canadian trial court for the first time accepted expert evidence on coercive control, as opposed to battered woman syndrome, in Stark's testimony. As pointed out by Sheehy, the Crown unsuccessfully sought to exclude his testimony on the basis that he did not qualify as an expert, being neither a psychologist nor a psychiatrist. The case went to the Ontario Court of Appeal on another issue and the Crown did not challenge the qualification of Stark. Whilst this case does not provide a binding precedent for the admissibility of such evidence or such an expert it does provide some support - both because the trial judge accepted the testimony and because the appellate court 'discussed [Stark's] evidence of coercive control ... without criticism or reservation' ${ }^{201}$ Stark also provided testimony in the UK case of $R v$ Challen. ${ }^{202}$ Although his testimony was not relied upon by the judge in the particular case because the issue was diminished responsibility and it was felt that the psychiatrist was able to explain coercive

195 [2014] VSC 304, [33]-[34] (Hollingworth J).This expert evidence was introduced through Victorian legislation (Crimes Act 1958 (Vic) s 322M - originally s 9AH). However, the legislation restates the common law: Douglas, 'Social Framework Evidence' (n 25) 93. [1993] QCA 480, 29-30 (Fitzgerald P and Davies JA).

197 [2003] NSWSC 194, [32]-[35] (Buddin J).

198 (2017) 51 WAR 359, 402 [183]-[186] (The Court). Commentary and extrajudicial analyses suggest that expert evidence from a social science perspective about the nature of IPV is admissible under the common law in homicide trials: Victorian Law Reform Commission, Defences to Homicide: Final Report (Final Report, October 2004) 183-4; Law Reform Commission of Western Australia, Review of the Law of Homicide (Final Report No 97, September 2007), 292-4; Australian Law Reform Commission and New South Wales Law Reform Commission, Family Violence: A National Legal Response (Final Report, October 2010) 623-5; 1250-2. This has been recognised judicially: DPP (Vic) v Parker (2016) 258 A Crim R 527, 538-9 [39] (The Court).

199 Liyanage (2017) 51 WAR 359, 383 [92] (The Court). In part the reasoning for limiting evidence to this issue was based on previous cases that had determined that 'it was the counterintuitive nature of the psychological impact of prolonged exposure to domestic violence which justified the admission of evidence of that kind': at 383 [92]-[94].

200 Transcript of Proceedings (Ottawa Superior Court of Ontario, 15 June 2008); (2011) 276 OAC 117.

201 Sheehy (n 20) 111. Dr Stark has provided testimony 'as an expert in some 70-80 civil and criminal matters' in the United States: at 106. 
control as it related to the defendant's mental health issues, such evidence was not rejected for future cases. ${ }^{203}$

Depending on the service they work for and their experience and training, some social workers and counsellors at frontline services may be recognised as a person with specialised expertise. ${ }^{204}$ Community members may also be identified as experts about social entrapment and specifically structural inequality. As noted, in $R v$ Yildiz the Court of Criminal Appeal of Victoria held that evidence of cultural values in the Turkish Australian community was admissible. ${ }^{205}$ The Court accepted that the expert in this case had developed his expertise through being born in and growing up within the Turkish community, and he was an expert about this population's attitudes towards social issues. ${ }^{206}$ Similar testimony has been accepted in the form of cultural reports for the purposes of sentencing in New Zealand. ${ }^{207}$ Such experts may be able to provide evidence about cultural attitudes to IPV and disclosure, contacting police and so on. Notably in $R v$ Kina, a sociolinguist was recognised as an expert about the communication approaches of Aboriginal people, identifying why the primary victim, Robin Kina, had not disclosed the history of abuse to her lawyers for the purposes of constructing her criminal defence. ${ }^{208}$ A member of the New Zealand Family Violence Death Review Committee gave expert evidence of the three dimensions of social entrapment in $R v$ Ruddelle. ${ }^{209}$

\section{CONCLUSION}

Ultimately we make four key points in this article. First, we draw on previous research that has shown that IPV is better understood as a form of social entrapment ${ }^{210}$ and contend that the paradigm of social entrapment should be used to understand facts in homicide trials involving IPV where the primary victim ultimately kills her aggressor.

Second, we recognise that where evidence of self-defence is raised, to convict the primary victim of murder the jury must be satisfied beyond reasonable doubt that she did not act in self-defence when she killed her abuser. ${ }^{211}$ Therefore, evidence about the three dimensions of social entrapment (the coercive and controlling behaviours of the predominant aggressor and their impact on the victim over time, the family violence safety response and structural intersectionality) is

203 Ibid [62] (Lady Hallett).

204 Liyanage (2017) 51 WAR 359, 398 [164] (The Court).

205 (1983) 11 A Crim R 115, 119 (Young CJ).

206 Ibid.

207 Solicitor-General v Heta [2019] 2 NZLR 241.

$208 R v$ Kina [1993] QCA 480, 35 (Fitzgerald P and Davies JA).

209 [2019] NZHC 2973. See also $R v$ Ruddelle [2020] NZHC 1983.

210 Ptacek (n 7) 10; Tolmie et al (n 2); Family Violence Death Review Committee, Fifth Report (n 7).

211 Recall Zecevic v DPP (Vic) (1987) 162 CLR 645, 657 (Wilson, Dawson and Toohey JJ): 'once the evidence discloses the possibility that the fatal act was done in self-defence' the burden shifts to the prosecution to disprove that the fatal act was not done in self-defence beyond reasonable doubt. 
necessary to assist the jury in making a proper assessment of whether the prosecution is able to disprove that the victim believed, on reasonable grounds, that defensive force was necessary.

Third, it is ultimately for the prosecution to prove beyond a reasonable doubt that the primary victim unreasonably believed that she had no other ways of preserving herself from death or very serious harm, than killing the primary aggressor. The prosecution therefore needs to disprove social entrapment on the facts and should not be able to make out their case by shifting the burden onto the defendant to prove entrapment or by relying on outmoded assumptions about the nature of family violence that are contradicted by the social science evidence.

Fourth, we identify a range of questions that should be answered by evidence, including potentially expert evidence, in ensuring that the jury understands social entrapment. We recognise that presenting evidence of social entrapment through an expert is not an ideal approach, rather such an understanding should frame every decision-maker's approach to the facts of the individual case. Nevertheless, we take a pragmatic approach and show that social entrapment and its three dimensions is an area of specialised knowledge and could be presented by an expert. While expert psychologists and psychiatrists have often been called in murder trials involving IPV, their evidence is focussed on the workings of the human mind. We suggest that expert testimony about understanding patterns of abusive behaviour in their social context would be appropriately provided by a social scientist or a social worker with expertise in this area. 


\section{University Library}

\section{- M M N E R VA A gateway to Melbourne's research publications}

Minerva Access is the Institutional Repository of The University of Melbourne

Author/s:

Douglas, $\mathrm{H} ;$ Tarrant, S;Tolmie, J

Title:

Social Entrapment Evidence: Understanding its Role in Self-Defence Cases Involving Intimate Partner Violence

Date:

2021-04-09

Citation:

Douglas, H., Tarrant, S. \& Tolmie, J. (2021). Social Entrapment Evidence: Understanding its Role in Self-Defence Cases Involving Intimate Partner Violence. University of New South Wales Law Journal, 44 (1), pp.324-354. https://doi.org/10.53637/vjii7190.

Persistent Link:

http://hdl.handle.net/11343/268115 